\title{
Effect of low oxygen tension on transcriptional factor OCT4 and SOX2 expression in New Zealand rabbit bone marrow-derived mesenchymal stem cells
}

\author{
Erma Safitri1,2 (D)
}

\begin{abstract}
1. Department of Veterinary Reproduction, Faculty of Veterinary Medicine, Universitas Airlangga, Surabaya 60115, Indonesia; 2. Stem Cells Research Division, Institute Tropical Disease, Universitas Airlangga, Surabaya 60115, Indonesia. Corresponding author: Erma Safitri, e-mail: erma-s@fkh.unair.ac.id
\end{abstract}

Received: 22-06-2020, Accepted: 14-10-2020, Published online: 18-11-2020

doi: www.doi.org/10.14202/vetworld.2020.2469-2476 How to cite this article: Safitri E (2020) Effect of low oxygen tension on transcriptional factor OCT4 and SOX2 expression in New Zealand rabbit bone marrow-derived mesenchymal stem cells, Veterinary World, 13(11): 2469-2476.

\begin{abstract}
Background and Aim: Octamer-binding transcription factor 4 (OCT4) and sex-determining region Y-box 2 (SOX2) are transcription factors whose functions are essential to maintain the pluripotency of embryonic stem cells. The purpose of this study was to derive stem cells for in vitro culture and to maintain their viability and pluripotency, with the goal to obtain a cell line for transplantation in patients with degenerative diseases or injuries. This research focused on examining the effect of low oxygen tension on the ability of bone marrow-derived mesenchymal stem cells (BM-MSCs) to express OCT4 and SOX2 in vitro.

Materials and Methods: BM-MSCs were obtained from femurs of 2000 to $3000 \mathrm{~g}$ New Zealand male rabbits. BM-MSCs were divided into three groups to test different culture conditions: A control group under hyperoxia condition $\left(21 \% \mathrm{O}_{2}\right)$ and two treatment groups with low oxygen tension $\left(1 \%\right.$ and $\left.3 \% \mathrm{O}_{2}\right)$. We characterized the BM-MSCs using flow cytometric measurement of cluster differentiation 44 (CD44) and cluster differentiation 90 (CD90) expression. The expression of OCT4 and SOX2 was measured by immunofluorescence staining after $48 \mathrm{~h}$ of incubation in chambers with normal or low oxygen tension with controlled internal atmosphere consisting of $95 \% \mathrm{~N}_{2}, 5 \% \mathrm{CO}_{2}$, and $1 \% \mathrm{O}_{2}$ ( $\mathrm{T} 1$ ) and $3 \% \mathrm{O}$ ( $\mathrm{T} 2$ ). We considered OCT4 and SOX2 as two markers of pluripotency induction. All immunofluorescence data were subjected to a post hoc normality Tukey's honestly significant difference test; all differences with $\mathrm{p}<5 \%$ were considered significant.
\end{abstract}

Results: BM-MSCs were positive for CD44 and CD90 expression after isolation. Oxygen tension culture conditions of $1 \%$ and $3 \% \mathrm{O}_{2}$ led to OCT4 and SOX2 expression on culture days 2 and $4(\mathrm{p}<0.05)$, respectively, as compared to the hyperoxia condition $\left(21 \% \mathrm{O}_{2}\right)$.

Conclusion: Based on the OCT4 and SOX2 immunofluorescence data, we conclude that the stem cells were pluripotent at low $\mathrm{O}_{2}$ tension (at $1 \% \mathrm{O}_{2}$ on day 2 and at $3 \% \mathrm{O}_{2}$ on day 4), whereas under $21 \% \mathrm{O}_{2}$ the OCT4 and SOX 2 were not expressed.

Keywords: bone marrow, cluster differentiation 44, cluster differentiation 90, culture in vitro, low $\mathrm{O}_{2}$ tension, mesenchymal stem cells, octamer-binding transcription factor 4, pluripotency, sex-determining region Y-box 2.

\section{Introduction}

Pluripotency is the ability of stem cells to differentiate into all cell types that constitute the adult body. Multipotent of rabbit's bone marrow-derived mesenchymal stem cells (BM-MSCs) can be induced to become pluripotent in vitro when cultured under low $\mathrm{O}_{2}$ tension conditions [1]. Low $\mathrm{O}_{2}$ tension is required to induce a favorable microenvironment to maintain MSCs in vitro, mimicking their BM niche [2], to ensure their viability for transplantation [3]. The low $\mathrm{O}$, tension in the BM helps to maintain stem cells adjusted to the body's normal physiological condition [4]. This maintenance would likely occur if the stem cells are in the G0 phase and not in a cycling state

Copyright: Safitri, E. Open Access. This article is distributed under the terms of the Creative Commons Attribution 4.0 International License (http://creativecommons.org/licenses/by/4.0/), which permits unrestricted use, distribution, and reproduction in any medium, provided you give appropriate credit to the original author(s) and the source, provide a link to the Creative Commons license, and indicate if changes were made. The Creative Commons Public Domain Dedication waiver (http://creativecommons.org/ publicdomain/zero/1.0/) applies to the data made available in this article, unless otherwise stated.
(G1/S/G2/M) [5]. However, MSCs non-proliferative and undifferentiated in vivo if there is no injury [6].

MSCs require physiological $\mathrm{O}_{2}$ tension levels to be $1 \%$ in the BM [7], $10-15 \%$ in the adipose tissue, and $2-9 \%$ in almost all other tissues [8]. Therefore, to obtain pluripotent characteristics in vitro, a low $\mathrm{O}_{2}$ tension has to be guaranteed during cell culture procedures to achieve their suitable physiological microenvironment. However, the optimal concentration and duration of low $\mathrm{O}_{2}$ tension to induce or maintain pluripotency have not yet been defined. Low $\mathrm{O}_{2}$ tension has been used in in vitro microenvironments to support several stem cell types: $0-5 \% \mathrm{O}_{2}$ for hematopoietic stem cells [5]; $2 \%$ for adipose stem cells [9], 1-5\% for neural stem cells (NSCs) [10], 3\% during 7 days for human cord blood cells [11], and $2 \%$ for MSCs [12]. Recent studies have focused on searching for the in vitro factor combination necessary to control the proliferation of stem cells that would enable them to remain viable and undifferentiated [13] and to prevent apoptosis, senescence, or gene mutations. 
In light of the potential therapeutic benefits that can derive from stem cell transplantation in patients with a degenerative disease or injury, understanding how to keep cell viability and pluripotency characteristics in vitro are of primordial importance [14]. Common in vitro culture conditions rely on hyperoxia (high $\mathrm{O}_{2}$ levels), which represents non-physiological environment for stem cells that are used to hypoxia (low $\mathrm{O}_{2}$ levels). Moreover, the pluripotency of stem cells in vitro is also affected by the cultivation time under low $\mathrm{O}_{2}$ conditions [15]. For example, after $48 \mathrm{~h}$ of low $\mathrm{O}_{2}$ tension, the role of the transcription factor hypoxia-inducible factor (HIF)- $1 \alpha$ is replaced by HIF-2 $\alpha$, which has different target genes [15]. The expression of HIF target genes in vitro was suggested to influence the expression of the pluripotency genes [16] octamer-binding transcription factor 4 (OCT4), sex-determining region Y-box 2 (SOX2), NANOG [17], reduced expression (REX-1) [18], Kruppel-like factor 4, and c-MYC [19].

The exact procedure to induce pluripotency in MSCs using low $\mathrm{O}_{2}$ tension in vitro before stem cell transplantation still remains unexplored. Therefore, this study aimed to determine the $\mathrm{O}_{2}$ concentration (comparing $1 \%, 3 \%$, and $21 \%$ ) and the culture time $(1,2,4$, and 8 days) required to achieve pluripotency of MSCs in vitro.

\section{Materials and Methods}

\section{Ethical approval}

All experimental protocols were reviewed and approved by the Animal Care and Use Committee, the Institutional Animal Ethics Committee (Veterinary Ethical Clearance), Faculty of Veterinary Medicine, Universitas Airlangga.

\section{Study period and location}

All experiments were conducted at Stem Cells Research Laboratory, Institute Tropical Disease, Universitas Airlangga, Surabaya 60115, Indonesia from January to April 2020.

\section{Animal source of MSCs}

Seven-month-old New Zealand male rabbits $( \pm 3000 \mathrm{~g})$ were housed in polycarbonate cages with 12-h light-dark cycle at a constant temperature of $21^{\circ} \mathrm{C}$. Rabbits were provided from Laboratory animal trial, Institute Tropical Disease, Universitas Airlangga, Surabaya 60115. Adult rabbits were provided a food pellet diet and fresh hay, vegetables, and water ad libitum. For the isolation of BM-MSCs, we used one femur from one male rabbit. The sampling technique of the BM-MSCs from the rabbit's femur was based on Lemeshow's method [20]. Animals were anesthetized before MSCs isolation.

\section{Isolation and culture of BM-MSCs}

The femur from a male rabbit $( \pm 3000 \mathrm{~g})$ was excised and its BM cells were slowly flushed out from the bone cavity. The BM aspirate was transferred to a $15 \mathrm{~mL}$ Heparin tube (Thermo Fisher $^{\circledR}$,
USA) previously filled with $3 \mathrm{~mL} \alpha$-minimum essential medium (Sigma-Aldrich ${ }^{\circledR}$, USA) supplemented with $10 \%$ inactivated fetal bovine serum (FBS), $2 \mathrm{~mL}$ L-glutamine (Sigma-Aldrich ${ }^{\circledR}$, USA), and $100 \mathrm{U} / \mathrm{mL}$ penicillin and streptomycin (Thermo Fisher, USA). The final concentration was $10 \mathrm{~mL}$. The aspirate was then transferred to a $15 \mathrm{~mL}$ sterile tube and diluted with $1 \times$ sterile phosphate-buffered saline (PBS) (Sigma-Aldrich, USA) to a total volume of $8 \mathrm{~mL}$ maintaining a neutral $\mathrm{pH}$. The tube was then rinsed twice with $5 \mathrm{~mL}$ PBS and then the aspirate was transferred to Ficoll solution (Sigma-Aldrich ${ }^{\circledR}$, USA) in a separated $15 \mathrm{~mL}$ tube. The aspirate was then coated with Ficoll before being centrifuged (Sorvall ${ }^{\mathrm{TM}}$ MX MicroUltracentrifuge, Thermo Fisher, USA) at $1600 \mathrm{rpm}$ for $15 \mathrm{~min}$ at room temperature. After centrifugation, the collection was done from the "buffy coat" location on the surface of the Ficoll-PBS solution using a sterile Pasteur pipette and placed in a $15 \mathrm{~mL}$ tube (Thermo Fisher $^{\circledR}$, USA). Each sample was diluted with $1 \times$ PBS to a total volume of $15 \mathrm{~mL}$ and the tube was turned 3-5 times to achieve an even mix. Next, the sample was centrifuged at $1600 \mathrm{rpm}$ for $10 \mathrm{~min}$, the supernatant was discarded and cells were suspended in $8 \mathrm{~mL}$ of cell culture medium before heating. After seeding between $5 \mathrm{~cm}^{2}$ and $10 \mathrm{~cm}^{2}$ (appropriate 200 million) of cells on the plate, cells were incubated at $37^{\circ} \mathrm{C}$ and $5 \% \mathrm{CO}_{2}$ and allowed to attach. Approximately $24 \mathrm{~h}$ later, the media and cells that were not attached were discarded and the dish was washed twice with $5 \mathrm{~mL}$ pre-heated $1 \times$ PBS before $10 \mathrm{~mL}$ of fresh cell culture medium was added to the dish for further incubation. The cells were incubated at $37^{\circ} \mathrm{C}$ and $5 \% \mathrm{CO}_{2}$ and observed daily using an inverted microscope. Culture media were changed every 3 days. This process was continued until the cells reached a confluency of $80-90 \%$. Forty-eight hours before cell collection, cells were balanced in the incubator at $37^{\circ} \mathrm{C}$ in a humidified tissue culture incubator containing $5 \% \mathrm{CO}_{2}$ and $95 \%$ air. Non-adherent cells were removed after $24 \mathrm{~h}$ and the presence of MSCs was confirmed under an inverted microscope [20].

\section{Identification of surface markers of BM-MSCs by flow cytometry}

BM-MSCs were harvested by centrifugation at the end of the cell culture period and a single-cell suspension was prepared using trypsinization before flow cytometry analysis. Approximately $2 \times 10^{5}$ cells per sample were washed twice with PBS. Cells were then incubated in test tubes or microtiter plates with unlabeled or fluorescently conjugated antibodies and analyzed by flow cytometry (Becton Dickson FACSVerse, San Diego, USA). The antibodies for surface markers were a PerCP-Cy5.5 anti-human cross anti-rabbit CD45 (Cat \# 45-0459-42, Bioscience, Thermo Fisher, USA) and an anti-cluster differentiation 90 (CD90) FITC anti-rabbit CD90 (Bs-0778R, Biossusa, San Diego, USA). 


\section{Low $\mathrm{O}_{2}$ tension in MSCs culture}

At the third cell culture passage, BM-MSCs were collected and placed on culture dishes with a diameter of $5 \mathrm{~cm}$ at a density of $2 \times 10^{7}$ cells $/ \mathrm{cm}^{2}$. Iscove's Modified Dulbecco's medium was supplemented with 15\% FBS (as BM-MSCs stimulator supplement), and antibiotics (100 IU penicillin and $100 \mu \mathrm{g} / \mathrm{mL}$ streptomycin) and was used to culture cells at a temperature of $37^{\circ} \mathrm{C}$ and with a mixture of $5 \% \mathrm{CO}$, and $95 \%$ air [21]. Low $\mathrm{O}_{2}$ tensions (1 and 3\%) [22,23] were achieved by integrating the culture flask into a specialized incubator for low $\mathrm{O}_{2}$ tension (Modular Incubator Chamber).

The BM-MSCs at passage three post-isolation were divided into three treatment groups [22,23], each with ten replicates: Control group with BM-MSCs under hyperoxic conditions $\left(\mathrm{O}_{2}=21 \%\right)$; treatment Group 1 with BM-MSCs under $1 \% \mathrm{O}$ tension; and treatment Group 2 with BM-MSCs under 3\% $\mathrm{O}_{2}$ tension. All groups were cultured for $1,2,4$, or 8 days.

\section{Analysis of pluripotency induction}

The analysis of the pluripotency induction was based on the identification of OCT4 and SOX2 proteins by immunofluorescence staining [24,25]. For this, MSCs were harvested, collected in a $15 \mathrm{~mL}$ tube, and fixed with methanol. After $15 \mathrm{~min}$, rabbit FITCconjugated anti-OCT4/POU5F1 polyclonal antibody Cat \# 45-0459-42, Bioscience, Thermo Fisher, USA) and rabbit FITC-conjugated anti-SOX2 polyclonal antibody (Cat. No bs-0523R-FITC; Biossusa) were added. The samples were washed with PBS, placed on glass slide and then incubated in incubator at $37^{\circ} \mathrm{C}$ for $1 \mathrm{~h}$ so that it adheres and finally analyzed under a fluorescence microscope [21,25].

\section{Statistical analysis}

The immunofluorescence data were analyzed using the IBM SPSS Statistics 20.0 (IBM Corp., NY, USA) and subjected to a post hoc normality Tukey's honestly significant difference test; all differences with $\mathrm{p}<5 \%$ were considered significant.

\section{Results}

BM-MSCs are multipotent stem cells and thus do not express pluripotent cell-specific transcription factors such as OCT4 and SOX2. We tested whether low $\mathrm{O}_{2}$ tension could induce rabbit BM-MSCs to become pluripotent in vitro. After being cultured under hypoxic $\left(1 \%\right.$ or $\left.3 \% \mathrm{O}_{2}\right)$ or normoxic $\left(21 \% \mathrm{O}_{2}\right)$ conditions, we characterized the OCT4 and SOX2 expression in BM-MSCs by immunofluorescence. We observed that OCT4 and SOX2 positive cells appeared after 2 and 4 days under $1 \%$ and $3 \% \mathrm{O}_{2}$ tension conditions (Figures-1-4), respectively, whereas under normal $\mathrm{O}_{2}$ tension OCT4 and SOX2 expression was not identified $(\mathrm{p}<0.05)$ (Figures-5 and 6). Of note, the fluorescence intensity on day 4 at $3 \%{ }_{0} 2$ tension was lower than on day 2 at $1 \%{ }_{0} 2$ tension $(p<0.05)$ (Tables- 1 and 2 or Figures- 7 and 8 for complete immunofluorescence quantification). This suggests that the

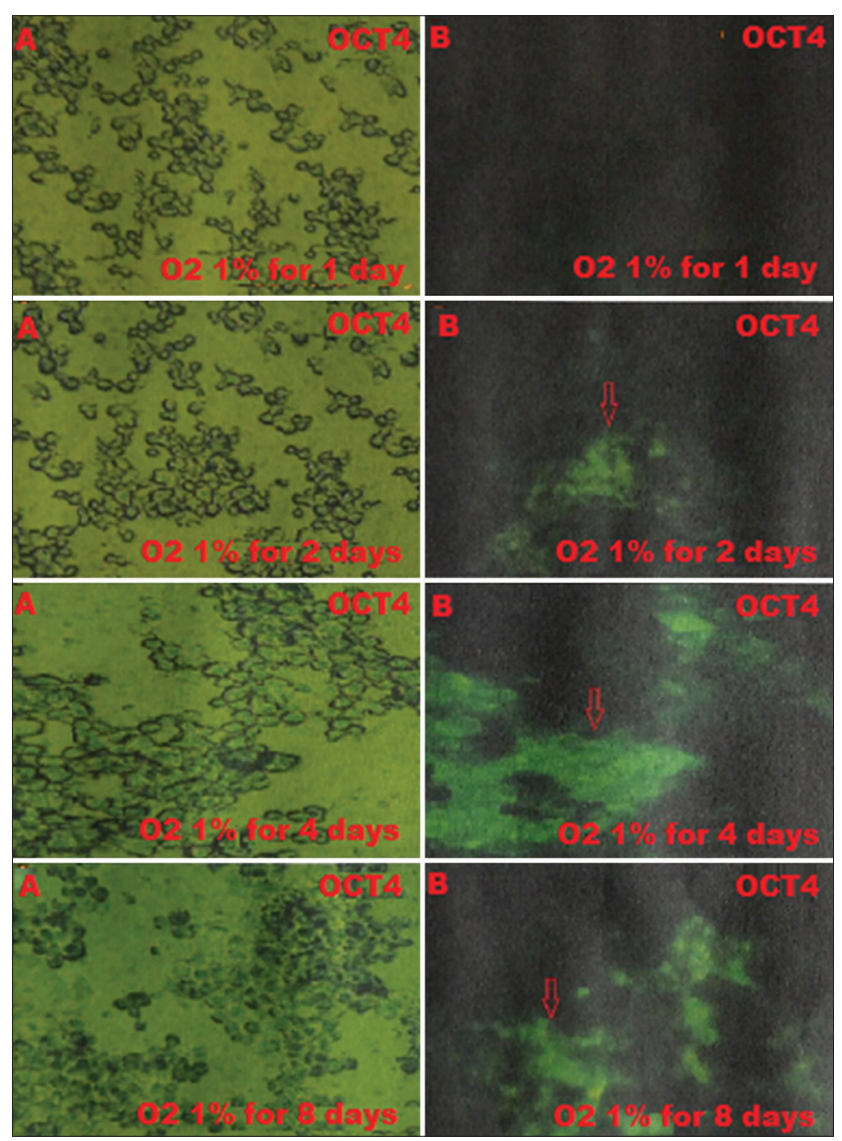

Figure-1: The positive expression on day 2 of the octamerbinding transcription factor 4 (OCT4) is $1 \% \mathrm{O}_{2}$ in hypoxic precondition treatment group during which cultivation time is $1,2,4$, and 8 days using fluorescence microscope; (A) without a filter and microscope $(400 \times)$; (B) containing a green filter, OCT4 positively shows green fluorescence (red arrow).

hypoxic conditioning led to the expression of transcription factors potentially enabling the BM-MSCs to become pluripotent. Furthermore, this observation indicates that the cultivation time under a specific $\mathrm{O}_{2}$ tension also plays an important role in the timing of OCT4 and SOX2 expression after isolation.

Overall, this result shows that the treatment with low $\mathrm{O}_{2}$ tension leads to the expression of the pluripotency transcription factors OCT4 and SOX2 in otherwise multipotent BM-MSCs, which may indicate that some cells were induced to become pluripotent.

\section{Discussion}

Our analysis of pluripotency based on OCT4 and SOX2 immunofluorescence. The study found that human ESC cultured for $48 \mathrm{~h}$ under low $\mathrm{O}_{2}$ conditions expressed HIF2- $\alpha$, which was shown to be an upstream regulator of OCT4 and therefore essential for the maintenance of pluripotency. Interestingly, other transcription factors, such as SOX2 and NANOG, are also regulated by HIF2- $\alpha$ [15]. Furthermore, OCT4, SOX2, and NANOG maintain stem cell characteristics and suppress the expression of differentiation genes.

The relationship between hypoxia, HIF2- $\alpha$, and pluripotency genes was previously highlighted by a 
Table-1: Score of OCT4 in 1, 2, 4, and 8 days in some treatments.

\begin{tabular}{lcccc}
\hline Treatments & $\begin{array}{c}\text { Average OCT4 } \\
\text { expression } \\
\text { score } \pm \text { SD in } \\
\mathbf{1} \text { day }\end{array}$ & $\begin{array}{c}\text { Average OCT4 } \\
\text { expression } \\
\text { score } \pm \text { SD in } \\
\mathbf{2} \text { days }\end{array}$ & $\begin{array}{c}\text { Average OCT4 } \\
\text { expression } \\
\text { score } \pm \text { SD in } \\
\text { 4 days }\end{array}$ & $\begin{array}{c}\text { Average OCT4 } \\
\text { expression } \\
\text { score } \pm \text { SD in 8 days }\end{array}$ \\
\hline Conventional/ Hyperoxia $\mathrm{O}_{2} 21 \%(\mathrm{C})$ & $0.13^{\mathrm{a}} \pm 0.50$ & $0.14^{\mathrm{a}} \pm 0.35$ & $0.15^{\mathrm{a}} \pm 0.60$ & $0.15^{\mathrm{a}} \pm 0.50$ \\
Low $\mathrm{O}_{2}$ tension $\mathrm{O}_{2} 1 \%(\mathrm{~T} 1)$ & $0.40^{\mathrm{a}} \pm 0.35$ & $1.75^{\mathrm{b}} \pm 0.55$ & $3.75^{\mathrm{c}} \pm 0.45$ & $3.70^{\mathrm{c}} \pm 0.40$ \\
Low $\mathrm{O}_{2}$ tension $\mathrm{O}_{2}$ 3\% (T2) & $0.25^{\mathrm{a}} \pm 0.50$ & $0.50^{\mathrm{a}} \pm 0.35$ & $1.50^{\mathrm{b}} \pm 0.30$ & $1.45^{\mathrm{b}} \pm 0.50$ \\
\hline
\end{tabular}

$a, b, c, d$ Different superscripts in the same column or row were significantly different $(p<0.005) .0 C T 4=$ Octamer-binding transcription factor $4, \mathrm{SD}=$ Standard deviation

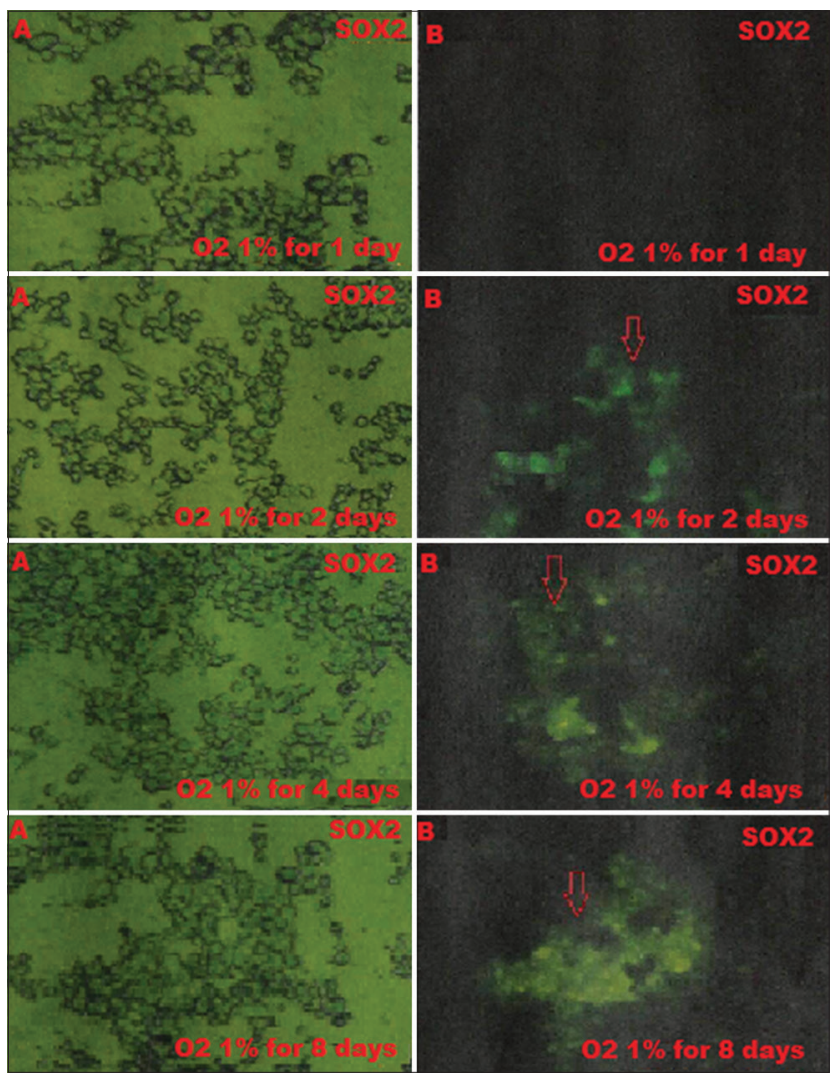

Figure-2: The positive expression on day 2 of sexdetermining region $\mathrm{Y}$-box 2 (SOX2) is $1 \% \mathrm{O}_{2}$ in hypoxic precondition treatment group during which cultivation time is $1,2,4$, and 8 days using the fluorescence microscope; (A) without filter and microscope $(400 \times)$; (B) with a green filter, SOX2 positively shows green fluorescence (red arrow).

study showing that the reprogramming efficiency during iPS cell generation from mouse embryonic fibroblasts was higher under hypoxia than under normoxia [26,27]. Furthermore, a study describing NSCs transplantation proposed that preconditioning under a hypoxic environment is necessary during cells in vitro maintenance [28]. This is in line with the high reliance of NSCs on low $\mathrm{O}_{2}$ during early development [29]. The therapeutic efficacy of stem cell transplantation requires adequate knowledge of the mechanisms that affect stem cells during their in vitro maintenance, such as migration, proliferation, commitment, and dependence on oxygen levels in the appropriate culturing conditions.

Hypoxic culture conditions were previously linked to the intracellular stabilization pathway of HIF

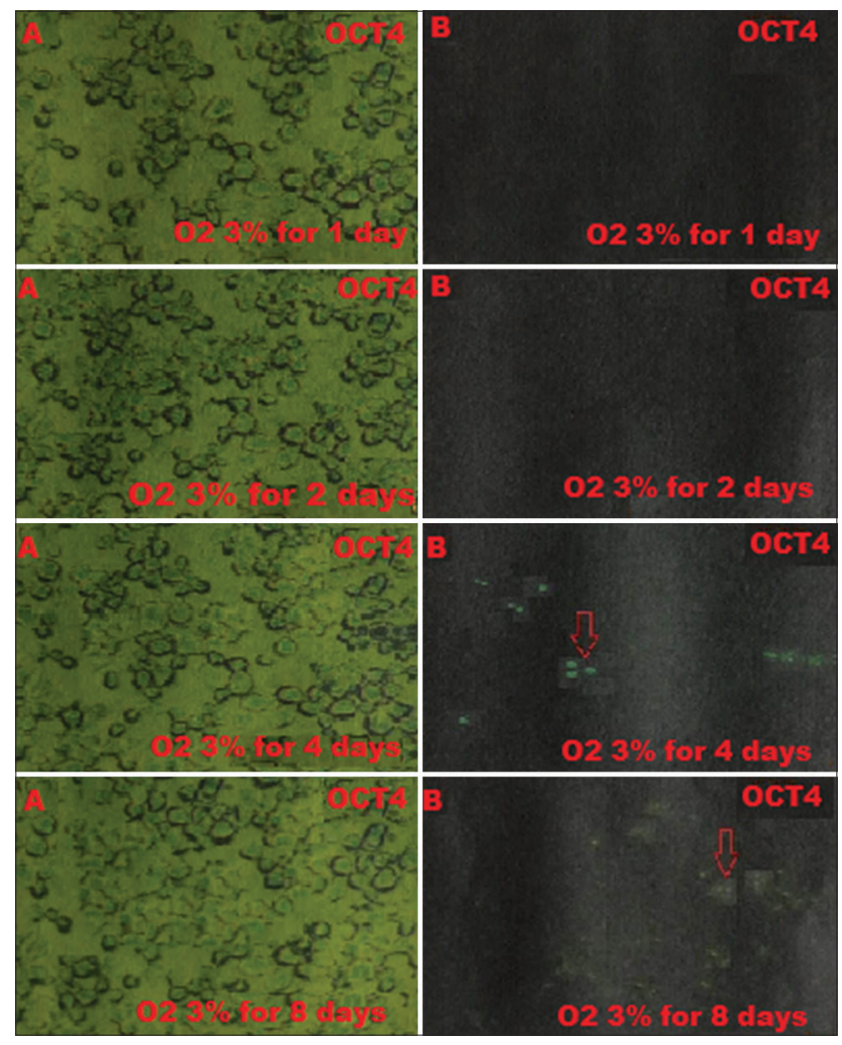

Figure-3: Positive expression on day 4 of the octamerbinding transcription factor 4 (OCT4) is $3 \% \mathrm{O}_{2}$ in hypoxic precondition treatment group during which cultivation time is $1,2,4$, and 8 days using the fluorescence microscope; (A) without filter and microscope $(400 \times)$; (B) with a green filter, OCT4 positively shows green fluorescence (red arrow).

transcription factors. Under low oxygen tension, the $\alpha$ subunit of the HIF (HIF- $\alpha$ ) becomes stable and dominant due to the absence of Proline hydroxylase activity [30], which under normoxia acts as a HIF inhibiting factor through oxygen-dependent hydroxylation of a conserved asparagine in the $\mathrm{COOH}$-terminal transactivation domain (CAD) of HIF- $\alpha$. When oxygen is not available, the asparagine residue is not hydroxylated and transcriptional co-activators such as p300/CBPCREB (cAMP-response element-binding protein) can interact with $\mathrm{CAD}$, triggering the complete activity of the cell's response to hypoxia through the stabilization of HIF1- $\alpha$. After HIF1- $\alpha$ is stabilized, it translocates from the cytoplasm to the nucleus and undergoes a dimerization with HIF1- $\beta$ [31], also called ARNT. The dimerization between HIF- $1 \alpha$ and HIF1- $\beta$ forms the HIF complex and requires the bHLH domain 
Table-2: Score of SOX2 in 1, 2, 4, and 8 days in some treatments.

\begin{tabular}{lcccc}
\hline Treatments & $\begin{array}{c}\text { Average SOX2 } \\
\text { expression } \\
\text { score } \pm \text { SD in } \\
\mathbf{1} \text { day }\end{array}$ & $\begin{array}{c}\text { Average SOX2 } \\
\text { expression } \\
\text { score } \pm \text { SD in } \\
\mathbf{2} \text { days }\end{array}$ & $\begin{array}{c}\text { Average SOX2 } \\
\text { expression } \\
\text { score } \pm \text { SD in 4 days }\end{array}$ & $\begin{array}{c}\text { Average SOX2 } \\
\text { expression score } \pm \text { SD } \\
\text { in 8 days }\end{array}$ \\
\hline Conventional/Hyperoxia $\mathrm{O}_{2} 21 \%(\mathrm{C})$ & $0.12^{\mathrm{a}} \pm 0.40$ & $0.14^{\mathrm{a}} \pm 0.50$ & $0.15^{\mathrm{a}} \pm 0.40$ & $0.15^{\mathrm{a}} \pm 0.30$ \\
Low $\mathrm{O}_{2}$ tension $\mathrm{O}_{2} 1 \%(\mathrm{~T} 1)$ & $0.30^{\mathrm{a}} \pm 0.40$ & $1.95^{\mathrm{b}} \pm 0.45$ & $2.75^{\mathrm{c}} \pm 0.35$ & $2.95^{\mathrm{c}} \pm 0.50$ \\
Low $\mathrm{O}_{2}$ tension $\mathrm{O}_{2}$ 3\% (T2) & $0.20^{\mathrm{a}} \pm 0.50$ & $0.40^{\mathrm{a}} \pm 0.40$ & $1.25^{\mathrm{b}} \pm 0.40$ & $1.40^{\mathrm{b}} \pm 0.55$ \\
\hline
\end{tabular}

$a, b, c, d$ Different superscripts in the same column or row were significantly different $(p<0.005)$. SOX $2=$ Sex-determining region Y-box 2, SD=Standard deviation

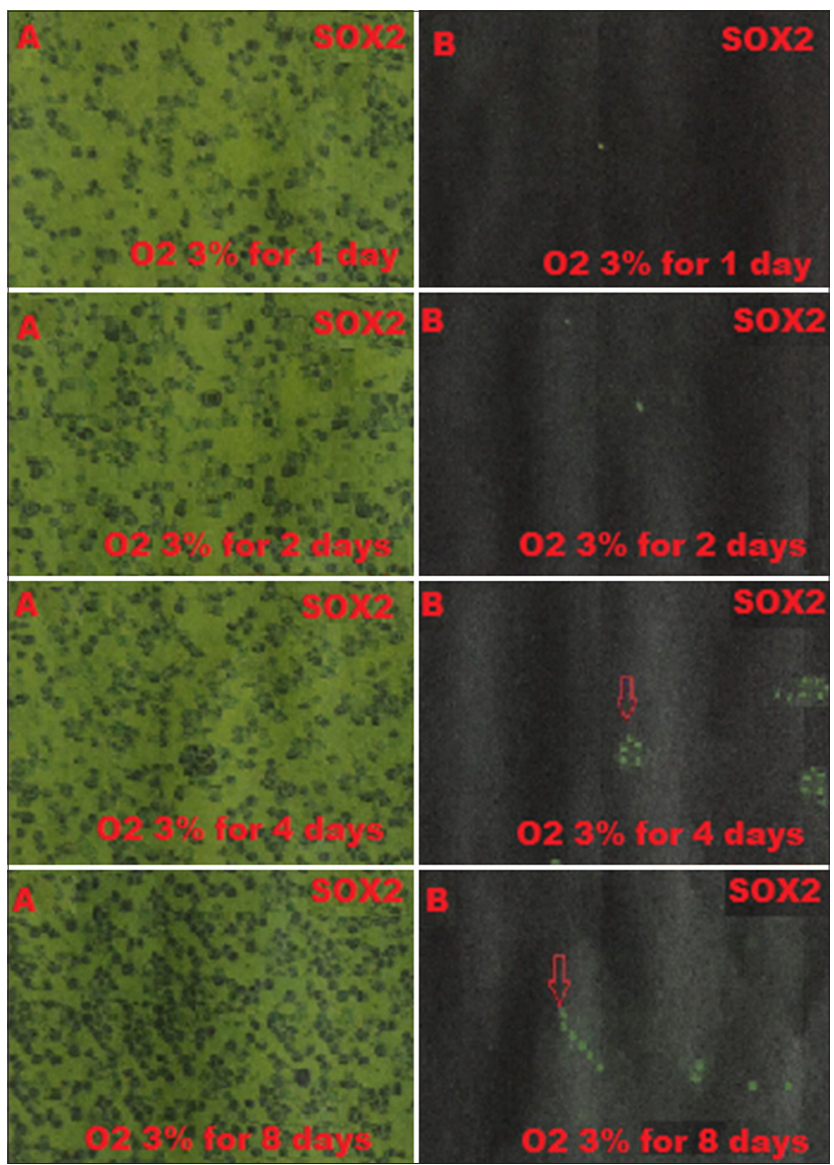

Figure-4: Positive expression on day $4^{\text {th }}$ of the sexdetermining region $\mathrm{Y}$-box $2(\mathrm{SOX} 2)$ is $3 \% \mathrm{O}_{2}$ in hypoxic precondition treatment group during which cultivation time is $1,2,4$, and 8 days using fluorescence microscope; (A) without filter and microscope $(400 \times)$; (B) with a green filter, SOX 2 positively shows green fluorescence (red arrow).

and parts of the periodic acid-Schiff (PAS) domain. The bHLH domain was described to be also important for the binding of the HIF complex to DNA [32] in specific DNA sequences, which are referred to as hypoxia response elements (HREs; 5'-TACGTG-3'), activating the expression of target genes. Of note, the $\mathrm{N}$-terminal transactivating domain confers target gene specificity to HIF [33].

Conversely, under normoxic conditions, cells trigger the degradation pathway of HIF- $1 \alpha$ through the oxygen-sensitive hydroxylation of the HIF $1-\alpha$ subunit [34]. HIF $1-\alpha$ contains many proline (Pro) amino acid residues, namely, in the oxygen-dependent degradation domains, which are hydroxylated by propyl hydroxylases (PHDs). PHDs catalyze this reaction

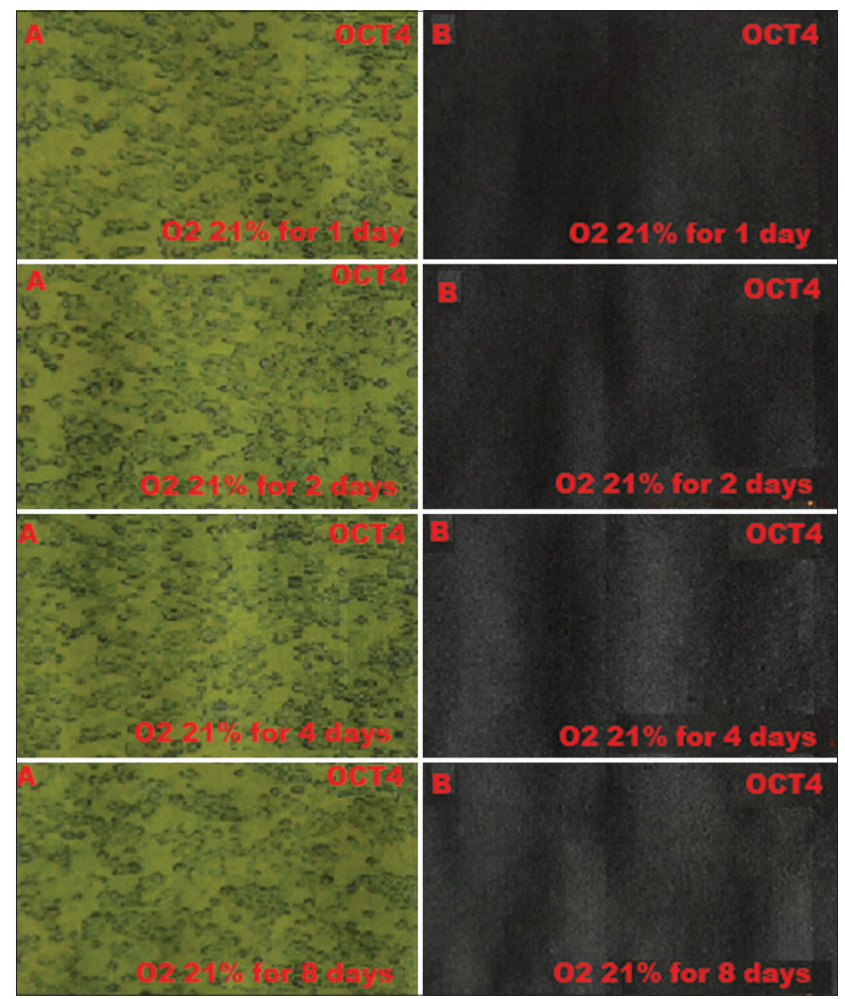

Figure-5: The negative expression of octamer-binding transcription factor 4 (OCT4) in $21 \% \quad \mathrm{O}_{2}$ normoxia during which cultivation time is $1,2,4$, and 8 days using fluorescence microscope; (A) without filter and microscope $(400 \times)$; (B) with green filter, OCT4 negatively does not show green fluorescence.

through the addition of oxygen in the Pro-402 and Pro-564 residues turning them into 4-hydroxyproline. Oxygen and 2-oxoglutarate are required for the activity of three PHD isoforms (PHD1, PHD2, and PHD3), which have an equally high dependence on oxygen [34]. Following hydroxylation, HIF-1 $\alpha$ is destabilized, ubiquitinated, and then degraded by the proteasome [35]. According to Vriend and Reitter [36], the von-Hippel-Lindau E3 ubiquitin ligase, tumor suppression, plays an important role in the regulation of the ubiquitination process of HIF- $1 \alpha$ by binding to its hydroxylation subunit. Moreover, this study showed that HIF-1 $\alpha$ degradation culminates in the absence of OCT4 and SOX2 expression in culture of BM-MSCc.

Our study infers the pluripotency activity in BM-MSCs after low $\mathrm{O}_{2}$ treatment, which is one of the main research focuses on the adult stem cells field. The balance between differentiation, apoptosis, and 

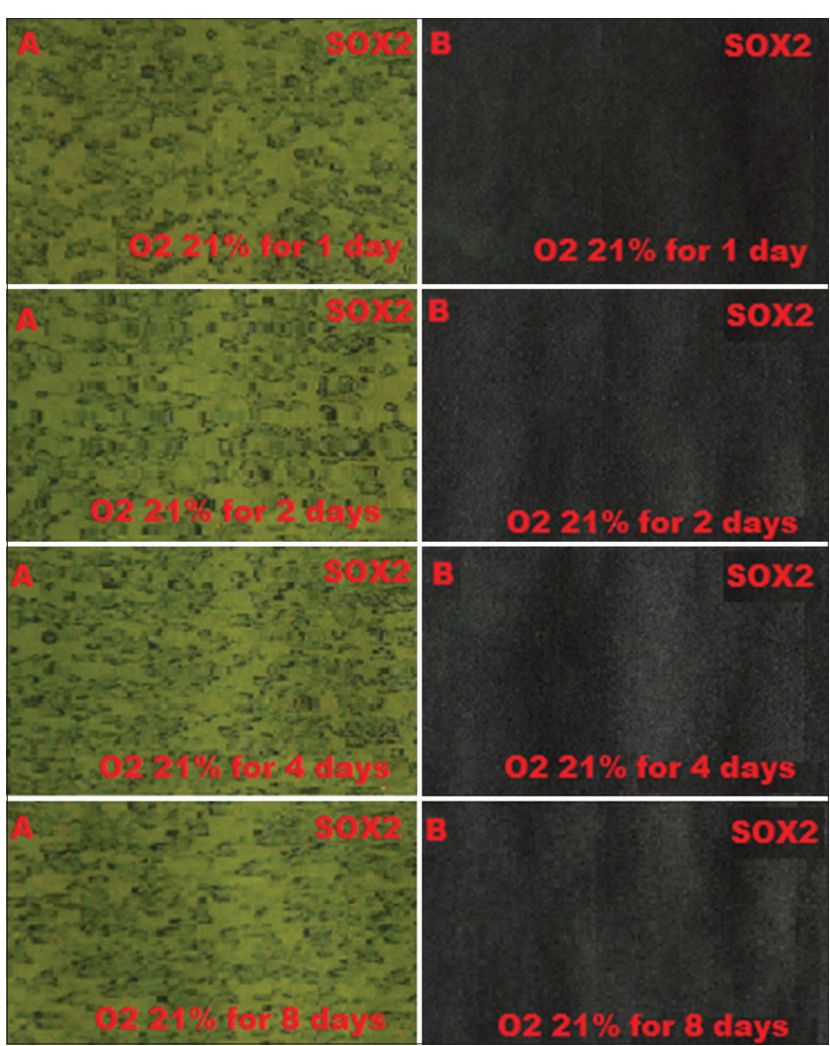

Figure-6: Negative expression of sex-determining region Y-box 2 (SOX2) in $21 \% \mathrm{O}_{2}$ normoxia during which cultivation time is $1,2,4$, and 8 days using fluorescence microscope; (A) without filter and microscope $(400 \times)$; (B) with green filter, SOX24 negatively does not show green fluorescence.

self-renewal, characteristic of stem cells, needs to be achieved through the regulation by the microenvironmental niche where the stem cells are located. According to Mohyeldin et al. [37], in feeder-free in vitro culture conditions, the fate of the stem cells is affected by growth factors, interleukins, and serum composition, but is also influenced by the oxygen levels used for cell culture.

Pluripotency, the ability of a cell to differentiate into any cell belonging to the three embryonic layers (ectoderm, mesoderm, and endoderm), is generally an exclusive characteristic of ESCs. Compared to more committed progenitor cells, stem cells, in particular, ESCs possess a higher differentiation potential [13]. ESCs are derived from the inner cell mass of the blastocyst and are easy to differentiate in vitro into various types of cells, including nerve, blood, cardiac, and immune cells. In this study, we show that MSCs, adult stem cells that are generally defined as multipotent, can express OCT4 and SOX2 genes after being cultured under low $\mathrm{O}_{2}$ tension. In the future, we expect to confirm that MSCs cultured under these in vitro conditions have a pluripotent potential and are also fully capable of differentiating into different cell types. This hypothesis is based on other studies, which show high efficiency of cell reprogramming to iPS cell state under low $\mathrm{O}_{2}$ tension conditions [26].

\section{Conclusion}

Based on immunofluorescence measurements, we suggest that some BM-MSCs have pluripotency

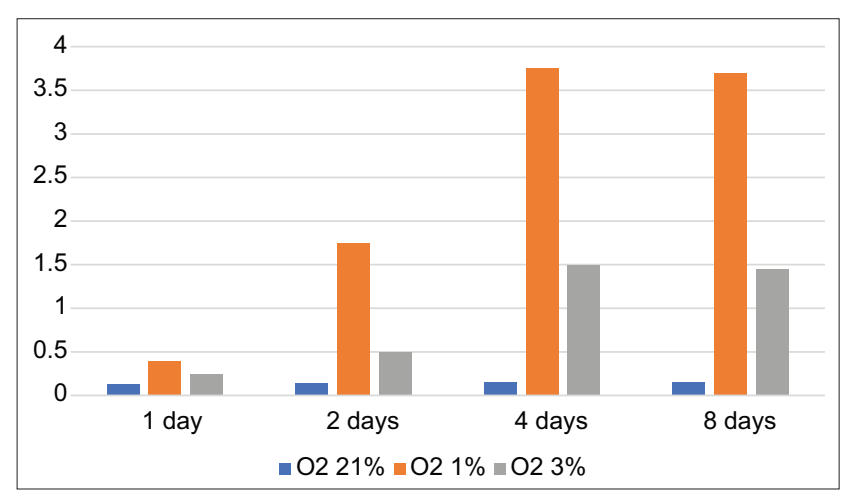

Figure-7: Score of octamer-binding transcription factor 4 in $1,2,4$, and 8 days in some treatments.

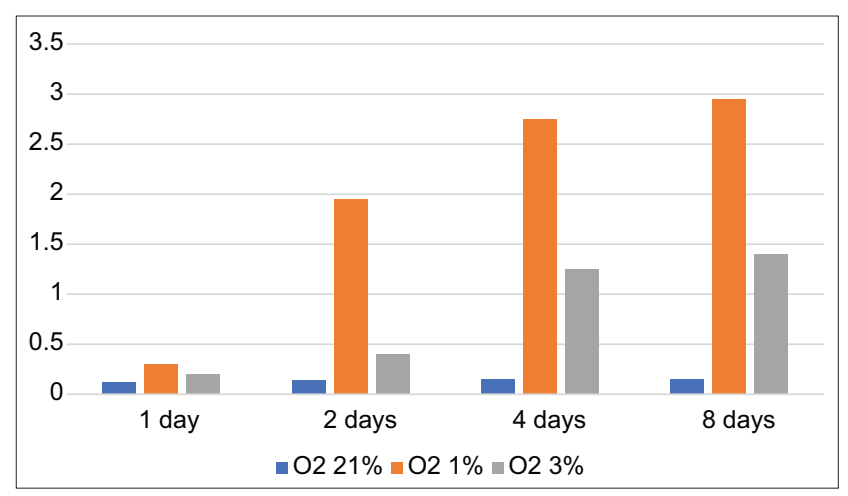

Figure-8: Score of sex-determining region $\mathrm{Y}$-box 2 in 1,2 , 4 , and 8 days in some treatments.

characteristics since they express OCT4 and SOX2 at low $\mathrm{O}_{2}$ tension (after 2 days under $1 \% \mathrm{O}_{2}$ and after 4 days under $3 \% \mathrm{O}_{2}$ tension), whereas at $21 \% \mathrm{O}_{2}$ tension OCT4 and SOX2 were not expressed. Thus, we conclude that in vitro low oxygen tension conditions increase OCT4 and SOX2 expression $(\mathrm{p}<0.05)$ as compared to conventional or hyperoxic conditions.

\section{Author's Contributions}

ES: Conceptualization, methodology, data analysis, research and ethical clearance preparation of the research equipment, observation of Immunofluorescence method (OCT4 and SOX2), draft for manuscript preparation. Preparation of animal experimental and corresponding author. She has read and approved the final manuscript.

\section{Acknowledgments}

The study was supported by funding from the Directorate General of Higher Education, Indonesia (DIKTI) 2020, The National Education Ministry, Republic of Indonesia, based on Decree number: 27/ $\mathrm{E} 1 / \mathrm{KPT} / 2020$ and agreement Contract number 4/ AMD/E1/KP.PTNBH/2020 and 765/UN3.14/PT2020.

\section{Competing Interests}

The author declares that she has no competing interests.

\section{Publisher's Note}

Veterinary World remains neutral with regard to jurisdictional claims in published institutional affiliation. 


\section{References}

1. Safitri, E., Prasetyo, R.H., Hariadi, M. and Srianto, P. (2018) Hypoxic precondition for inducing pluripotency of rabbit's bone marrow-derived mesenchymal stem cells. Biochem. Cell. Arch., 18(2): 1509-1517.

2. Lambertini, E., Penolazzi, L., Angelozzi, M., Bergamin, L.S., Manferdini, C., Vieceli, D. S.F., Paolella, F., Lisignoli, G. and Piva, R. (2018) Hypoxia preconditioning of Human MSCs: a Direct Evidence of HIF-1 $\alpha$ and Collagen Type XV Correlation. Cell Phys. Biochem., 51:2237-2249.

3. Safitri, E. and Hariadi, E. (2019) Comparison of biotechnological culture of hypoxia-conditioned rat mesenchymal stem cells with conventional in vitro culture of normoxia-conditioned rat mesenchymal stem cells for testicular failure therapy with low libido in rats. Vet. World, 12(6): 916-924

4. Safitri, E., Srianto, P., Widiyatno, T.V., Sandhika, W. and Prasetyo, R.H. (2018) Viability of rabbit adipocyte stem cells cultured under different oxygen concentrations in vitro. Philipp. J. Vet. Med., 55(1): 1-8.

5. Daignan-Fornier, B. and Sagot, I. (2011) Proliferation/quiescence: When to start? Where to stop? What to stock? Cell Div., 6(10): 1-5.

6. Rumman, M., Dhawan, J. and Kassem, M. (2015) Concise review: Quiescence in adult stem cells: Biological significance and relevance to tissue regeneration. Stem Cells, 33(10): 2903-2912.

7. Kim, D.S., Ko, Y.J., Lee, M.W., Park, H.J., Kim, Y.J., Sung, K.W., Koo, H.K. and Yoo, K.H. (2016) Effect of low oxygen tension on the biological characteristics of human bone marrow mesenchymal stem cells. Cell Stress Chaperones, 21(6): 1089-1099.

8. Gruber, M., Mathew, L.K., Runge, A.C., Garcia, J.A. and Simon, M.C. (2010) EPAS1 is required for spermatogenesis in the postnatal mouse testis. Biol. Reprod., 82(6): 1227-1236.

9. Shi, S., Xie, J., Zhong, J., Lin, S., Zhang, T., Sun, K., Fu, N., Shao, X. and Lin, Y. (2016) Effects of low oxygen tension on gene profile of soluble growth factors in co-cultured adipose-derived stromal cells and chondrocytes. Cell Prolif., 49(3): 341-351.

10. Mannello, F., Medda, V. and Tonti, G.A. (2011) Hypoxia and neural stem cells: From invertebrates to brain cancer stem cells. Int. J. Dev. Biol., 55(6): 569-581.

11. Ivanovic, Z., Hermitte, F., de la Grange, P.B., Dazey, B., Belloc, F., Lacombe, F., Vezon, G. and Praloran, V. (2004) Simultaneous maintenance of human cord blood SCIDrepopulating cells and expansion of committed progenitors at low $\mathrm{O}_{2}$ concentration (3\%). Stem Cells, 22(5): 716-724.

12. Fan, L., Liu, R., Li, L., Shi, Z., Dang, X. and Wang, K. (2015) Low oxygen tension enhances osteogenic potential of bone marrow-derived mesenchymal stem cells with osteonecrosis-related functional impairment. Stem Cell Int., 2015: $1-8$.

13. Halim, D.H., Murty, H., Sandra, F., Boediono, A., Djuwantono, T. and Setiawan, B. (2010) Stem Cell Dasar Teori Dan Aplikasi Klinis. $1^{\text {st }}$ ed. Erlangga, Indonesia. p154-196.

14. Masarani, M., Wazait, H. and Dinneen, M. (2006) Mumps orchitis. J. R. Soc. Med., 99(11): 573-575.

15. Forristal, C.E., Wright, K.L., Hanley, N.A., Oreffo, O. and Houghton, F.D. (2010) Hypoxia inducible factors regulate pluripotency and proliferation in human embryonic stem cells cultured at reduced oxygen tensions. Reproduction, 139(1): 85-97.

16. Youssef, A. and Han, V.K.M. (2016) Low oxygen tension modulates the insulin-like growth factor-1 or -2 signaling via both insulin-like growth factor-1 receptor and insulin receptor to maintain stem cell identity in placental mesenchymal stem cells. Endocrinology, 157(3): 1163-1174.

17. Seymour, T., Twigger, A.J. and Kakulas, F. (2015)
Pluripotency genes and their functions in the normal and aberrant breast and brain. Int. J. Mol. Sci., 16(11): 27288-27301

18. Festuccia, N., Osorno, R., Wilson, V. and Chambers, I. (2013) The role of pluripotency gene regulatory network components in mediating transitions between pluripotent cell states. Curr. Opin. Genet. Dev., 23(5): 504-511.

19. Neganova, I., Shmeleva, E., Munkley, J., Chichagova, C., Anyfantis, G., Anderson, R., Passos, J., Elliott, D.J., Armstrong, L. and Lako, M. (2016) JNK/SAPK signaling is essential for efficient reprogramming of human fibroblasts to induced pluripotent stem cells. Stem Cells, 34(5): 1198-1212.

20. Hussain, S., Tamizhselvi, R., George, L. and Manickam, V. (2016) Assessment of the role of noni (Morinda citrifolia) juice for inducing osteoblast differentiation in isolated rat bone marrow derived mesenchymal stem cells. Int. J. Stem Cells, 9(2): 221-229.

21. Eleotério, R.B., Sepúlveda, R.V., Reis, E.C.C., Valente, F.L. and Borges, A.P.B. (2016) Isolation, expansion and differentiation of mesenchymal stromal cells from rabbits' bone marrow. Pesq. Vet. Bras., 36(5): 423-430.

22. Safitri, E., Utama, S., Widiyatno, T.V., Sandhika, W. and Prasetyo, R.H. (2016) Auto-regeneration of mice testicle seminiferous tubules due to malnutrition based on stem cells mobilization using honey. Asian Pac. J. Reprod., 5(1): 30-34.

23. Prasetyo, R.H. and Safitri, E. (2016) Effects of honey to mobilize endogenous stem cells in efforts intestinal and ovarian tissue regeneration in rats with protein energy malnutrition. Asian Pac. J. Reprod., 5(3): 198-203.

24. Safitri E., Utama, S., Bumi, C., Aulani'am, A. and Rantam, F.A. (2014) Hypoxic preconditioning for viable and self renewing mesenchymal stem cells (MSCs) as the regeneration of spermatogenesis process. Adv. Nat. App. Sci., 8(8): 42-46.

25. De Miguel, M.P., Alcaina, Y., de la Maza, D.S. and LopezIglesias, P. (2015) Cell metabolism under microenvironmental low oxygen tension levels in stemness, proliferation and pluripotency. Curr. Mol. Med., 15(4): 343.

26. Rizzino, A. (2015) Concise review: The Sox2-Oct4 connection: Critical players in a much larger interdependent network integrated at multiple levels. Stem Cells, 31(6): 1033-1039.

27. Yoshida, Y., Takahashi, K., Okita, K., Ichisaka, T. and Yamanaka, S. (2009) Hypoxia enhances the generation of induced pluripotent stem cells. Cell Stem Cell, 5(3): 237-241.

28. Moreno, M., Fernandez, V., Monllau, J.M., Borrell, V., Lerin, C. and de la Iglesia, N. (2015) Transcriptional profiling of hypoxic neural stem cells identifies calcineurin-NFATc4 signaling as a major regulator of neural stem cell biology. Stem Cell Reports, 5(2): 157-165.

29. Wu, J., Sun, Z., Sun, S., Wu, J., Weisel, R.D. and Keating, A. (2008) Intravenously administered bone marrow cells migrate to damaged brain tissue and improve neural function in ischemic rats. Cell Transplant., 16(10): 993-1005.

30. Ivan, M., Kond, K., Yang, H., Kim, W., Valindo, J., Ohh, M., Saic, A., Asara, J.M., Lane, W.S. and Kaelin, W.G. Jr. (2001) HIFalpha targeted for VHL-mediated destruction by proline hydroxylation: Implications for $\mathrm{O}_{2}$ sensing. Science, 292(5516): 464-468.

31. Ku, Q. and Costa, M. (2006) Hypoxia-inducible factor-1 (HIF-1). Mol. Pharmacol., 70(5): 1469-1480.

32. Zagorska, A. and Dulak, J. (2004) HIF-1: The knowns and unknowns of hypoxia sensing. Acta Biochim. Pol., 51(3): 563-585.

33. Tuckerman, J.R., Zhao, Y., Hewitson, K.S., Tian, Y.M., Pugh, C.W., Ratcliffe, P.J. and Mole, D.R. (2004) Determination and comparison of specific activity of the HIF-prolyl hydroxylases. FEBS Lett., 576(1-2): 145-150.

34. Ciria, M., Garcia, N.A., Ontoria-Oviedo, I., 
Gonzalez-King, H., Carrero, R., De La Pompa, J.L., Montero, J.A. and Sepulveda, P. (2017) Mesenchymal stem cell migration and proliferation are mediated by hypoxia-inducible factor- $1 \alpha$ upstream of notch and SUMO pathways. Stem Cells Dev., 26(13): 973-985.

35. Fandrey, J., Gorr, T.A. and Gassmann, M. (2006) Regulating cellular oxygen sensing by hydroxylation. Cardiovasc. Res.,
71(4): 642-651.

36. Vriend, J. and Reitter, R.J. (2016) Melatonin and the von hippel-Lindau/HIF-1 oxygen sensing mechanism: A review. Biochim. Biophys. Acta, 1865(2): 176-183.

37. Mohyeldin, A., Muvdi, T.G. and Hiojosa, A.Q. (2010) Oxygen in stem cell biology: A critical component of the stem cell niche. Cell Stem Cell, 7(7): 150-161.

$* * * * * * * *$ 